\title{
La Niña Impacts on Austral Summer Extremely High-Streamflow Events of the Paranaíba River in Brazil
}

\author{
Netrananda Sahu, ${ }^{1}$ R.B. Singh, ${ }^{1}$ Pankaj Kumar, ${ }^{1}$ \\ Roberto Valmir Da Silva, ${ }^{2}$ and Swadhin K. Behera ${ }^{3}$ \\ ${ }^{1}$ Department of Geography, Delhi School of Economics, University of Delhi, Delhi 110007, India \\ ${ }^{2}$ Environmental Engineering, Federal University of Fronteira Sul, Erechim 181, Brazil \\ ${ }^{3}$ Research Institute for Global Change, JAMSTEC, Yokohama 236-0001, Japan
}

Correspondence should be addressed to Netrananda Sahu; babunsahu@gmail.com and R.B. Singh; rbsgeo@hotmail.com

Received 15 August 2013; Accepted 18 October 2013

Academic Editor: Xiangzheng Deng

Copyright (C) 2013 Netrananda Sahu et al. This is an open access article distributed under the Creative Commons Attribution License, which permits unrestricted use, distribution, and reproduction in any medium, provided the original work is properly cited.

The extremely high-streamflow events of the Paranaíba River basin are found to be associated with La Niña phenomenon during December-February (DJF). Extreme events are identified based on their persistent flow for seven days and more after taking retention time into consideration. The extremely high-streamflow events are associated with the La Niña years; $80 \%$ of the highstreamflow events have occurred during La Niña phases. Therefore, a very-significant $80 \%$ and above correspondence of the La Niña events and the seasonal streamflow anomalies are found in DJF. Although climate variations have direct relationship with the rainfall, streamflow variations are considered as the surrogates to rainfalls. However, apart from climate variations the anthropogenic and land-use changes also influence streamflow variations. In this study, we have applied multivelocity TOPMODEL approach and residual trend analysis to examine the impact of land-use to the streamflow at the Fazenda Santa Maria gauge stations. However, the model residual trend analysis of the TOPMODEL approach cannot quantify the extent of land-use impact. Thus, La Niña phase is important components to understand and predict the streamflow variations in the Paranaíba River basin.

\section{Introduction}

Streamflow plays a major role in the livelihood of the people in a river catchment. Hence, the scientific analysis of streamflow is very essential for the present and future generations. The influences of climate variability on the streamflows have been studied by Sahu et al., [1-3] in their previous studies of Indonesia, and found very good correlation of the impact of climate variability on the streamflow. Several studies performed on southeastern South America have used streamflows as indicators of climatic variability from the interannual to the seasonal scale [4-6]. It is stated that the climate variability and changes can be studied by analyzing river flows as a surrogate to rainfall, under the assumption that changes in the rainfall are reflected and likely amplified in streamflows $[7,8]$. Moreover, it is easier to detect a change in streamflow than to directly observe changes in the basic climatic variables [9].
The Paranaíba River flows in the Rio Paranaíba of Brazil and in the state of Minas Gerais of the Mata da Corda Mountains $\left(19^{\circ} 13^{\prime} 21^{\prime \prime} \mathrm{S}\right.$ and $\left.46^{\circ} 10^{\prime} 28^{\prime \prime} \mathrm{W}\right)$. The river is flowing at an altitude of 1,148 meters. The length of the river is approximately 1,000 kilometers. The Paranaíba and the Grande River both confluence and then form the second largest Parana River of Brazil, at the point to make the borders between the states of Sao Paulo and Minas Gerais [10]. The catchment area of the Paranaíba is approximately $36,000 \mathrm{~km}^{2}$. However, Fazenda Santa Maria gauge station $\left(17^{\circ} 58^{\prime} 51^{\prime \prime} \mathrm{S}\right.$ and $50^{\circ} 14^{\prime} 49^{\prime \prime} \mathrm{W}$, Figure 1) is in the Upper Paranaíba River catchment, having a catchment area of about $16,750 \mathrm{~km}^{2}$. The Upper catchment is not artificially regulated; thus, it is best suited for our analysis to minimize anthropogenic influences on streamflow [1]. This river is the primary source of water to the Parana River. The water resources of this basin sustain one of the most densely populated regions of South America, 

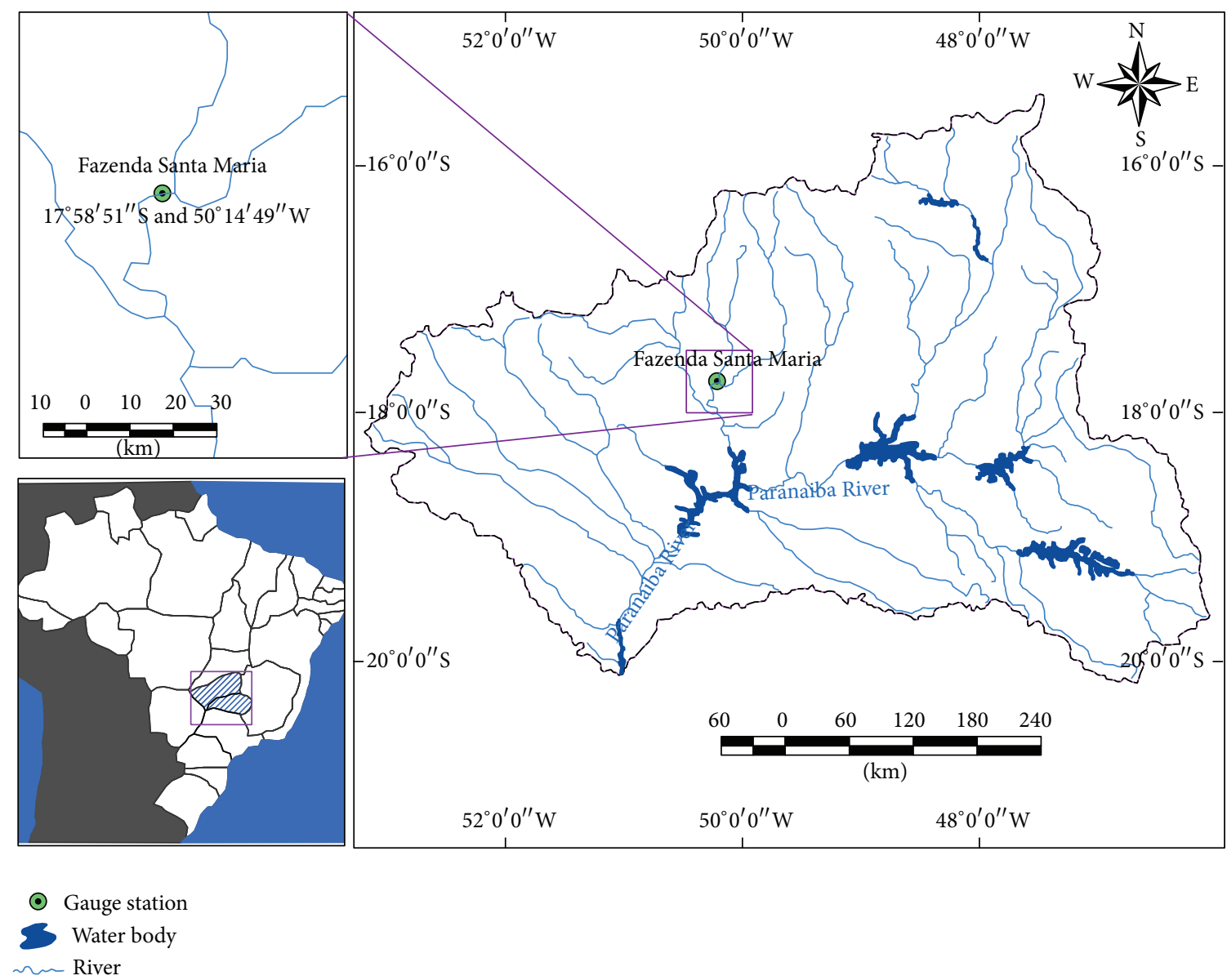

Figure 1: The Paranaiba River basin with Fazenda Santa Maria (green mark) gauge station.

where harvests and livestock are among the region's most important assets [10].

The physical characteristics of a river basin and the relationship between the climatic behavior of rainfall and its hydrologic response, through streamflow, can present different degrees of complexity $[1,11,12]$. Streamflow is a synthesis of precipitation and evapotranspiration and various components of the hydrologic cycle together with possible anthropogenic influences [13]. The rainfall variation in Northeast Brazil is shown to be influenced by variability in the tropical Atlantic besides El Niño/La Niña [14, 15]. In this study we investigate the ENSO (El Niño and Southern Oscillation) particularly La Niña relationship at the basin scale. The signature of La Niña is found in the extremely high discharge events of December-February (DJF) in the Paranaiba River basin. This paper also applies the hydrological model TOPMODEL [16] with a multivelocity approach in order to investigate the land-use change on discharges.

\section{Data and Methods}

2.1. Model Input Data. The topographic data used in this study were extracted by using ETOPO1 elevations global data from National Geophysical Data Center (NGDC), National
Oceanic and Atmospheric Administration (NOAA). The topographic data were composed of basin boundary, slopes, cells distances (distance to the next downward cell), cells areas, and cumulative areas. Precipitation data were obtained from ANA (Brazilian National Agency of Water Resources) in two stations: Fazenda Aliança and Maurilândia. Meteorological data (radiation and temperature) were extracted from Hirabayashi et al.s [17] reanalysis. They developed and assessed a global 0.5 degree near-surface atmospheric data from 1948 to 2006 at daily time scale; we used data from 19782006.

Potential evapotranspiration was estimated through the Priestley-Taylor radiation method [18]. As TOPMODEL is a lumped hydrological model, an aerial average daily precipitation (Figure 2) and evapotranspiration (Figure 3) data were used as input. For this period (1978-2006) the mean precipitation value was $3.94 \mathrm{~mm}$ with a maximum value of $108.95 \mathrm{~mm}$, whereas the mean evapotranspiration value was $4.11 \mathrm{~mm}$ with a maximum value of $6.37 \mathrm{~mm}$ and minimum value of $2.34 \mathrm{~mm}$. Daily discharges data were acquired from ANA at Fazenda Santa Maria station. They encompass the period from 1978 to 2006. The last six years (2001-2006) of this time series were used for model calibration purpose and the entire time series was used for model validation purpose. 


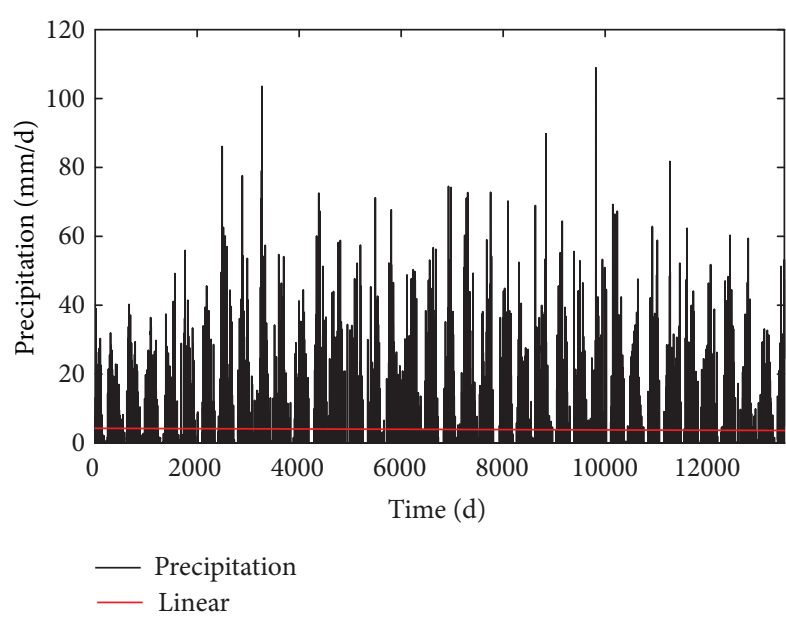

FIGURE 2: Areal daily precipitation from 1978 to 2006.

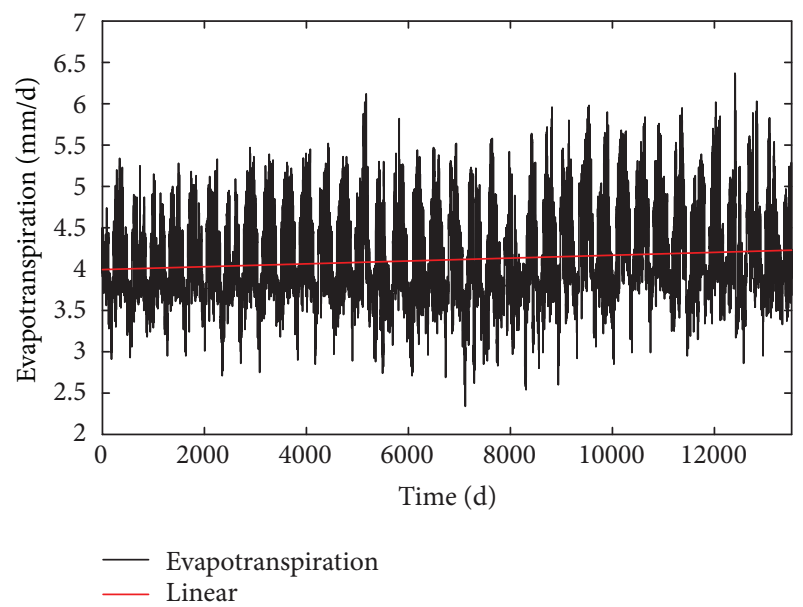

FIgURE 3: Areal daily evapotranspiration calculated with the Priestley-Taylor method from 1978 to 2006.

2.2. Climatology and Composite Index Data. Daily climatology and anomalies of river discharge are computed from the 29-year data. Extremely high discharge events were cataloged based on a threshold; $1.5 \sigma$ ( $\sigma$ stands for standard deviation) was set as threshold for extremely high discharges events. The NCEP/NCAR (National Centers for Environmental Prediction/National Center for Atmospheric Research) global atmospheric reanalysis-1 zonal wind $(850 \mathrm{hPa})$ dataset [19] is used from January 1, 1979 to December 31, 2008. The other major dataset used in this study is the global coverage NOAA interpolated of daily averages of outgoing longwave radiation anomalies (here after OLR) data on a $2.5^{\circ} \times 2.5^{\circ}$ grid at standard pressure levels from 1 January 1979 to 31 December 2008 [20]. In addition to these, the SST anomalies are used from the daily OISST analysis version 2 AVHRR-AMSR (Advanced Very High Resolution Radiometer-Advanced Microwave Scanning Radiometer) products from National Climate Data Center (NCDC) from 1981 to 2008 [21].

\section{Paranaíba Streamflow Characteristics}

The climatology of streamflow (Figure 4(a)) at the Fazenda Santa Maria gauge station of the Paranaíba River in Brazil shows significant flow from November to May and very little flow from June to October. The variation in this seasonal streamflow significantly affects the human population [10]. A linear trend is seen in the streamflow at the Santa Maria stations. During the season, we have found that the El Niño Modoki influence reduces the streamflow to nearly half of the average streamflow of the whole time series for extremely low-discharge events [3]. However, in this study we have investigated the influences of La Niña for extremely highstreamflow events (Figure 4(b)).

It is important to understand the underlying mechanisms that cause the variation of streamflows due to the influences of La Niña on the Paranaíba streamflows. A scientific analysis is made to link the streamflow variability with the rainfall and SST and OLR variations on daily time scale like the previous studies $[1,2]$. Apart from the climate variability impact, in this study we have applied multivelocity approach TOPMODEL to examine the land-use influences on the streamflow, because the river streamflows, unlike the rainfall, are affected by morphological and anthropogenic factors including soil and forestry recharge, sediment deposit, topography and land-use changes.

\section{Hydrological Model Approach}

The multivelocity model approach, which is consistent with field observations carried out by Leopold et al. [22], consists in deriving a time-area function from a distance-area function using the following equation:

$$
\mathrm{tc}_{k}=\sum_{k=1}^{N} \frac{l_{k}}{V_{\mathrm{CH}}^{\prime} A_{K}^{V_{R}^{\prime}}},
$$

where $\mathrm{tc}_{k}(T)$ is the time of concentration of a determined distance-area function class $k ; V_{C H}^{\prime}$ is a proportionality constant $\left(L^{-1} T^{-1}\right) ; V_{R}^{\prime}$ is a power law exponent $(-) ; l_{k}$ is the plan flow path length from a class area $k$ to the basin outlet; $A_{K}\left(L^{2}\right)$ is the cumulative area of the class $k$ and $N$ is the total number of classes which the distance-area function is composed. Details about this approach and its implementation may be seen in the work of Silva et al. [23,24].

In order to evaluate the model performance, Nash coefficient [25] and log Nash coefficient were chosen as follows:

$$
\begin{gathered}
\operatorname{NSE}(\Theta)=1-\frac{\sum_{t=1}^{N}(o(t)-\widehat{o}(t \mid \Theta))^{2}}{\sum_{t=1}^{N}(o(t)-\bar{o})^{2}}, \\
\mathrm{NSE}_{\log }(\Theta)=1-\frac{\sum_{t=1}^{N}(\ln (o(t))-\ln (\widehat{o}(t \mid \Theta)))^{2}}{\sum_{t=1}^{N}(\ln (o(t))-\ln (\bar{o}))^{2}},
\end{gathered}
$$

where $o(t)$ is the observed discharge at the time $t, \widehat{o}(t \mid \Theta)$ is the calculated discharge at the time $t$ given the parameter set $\Theta, o$ is the observed discharge average, and $N$ is the number of time steps. Thereby, the model performance (Em) 


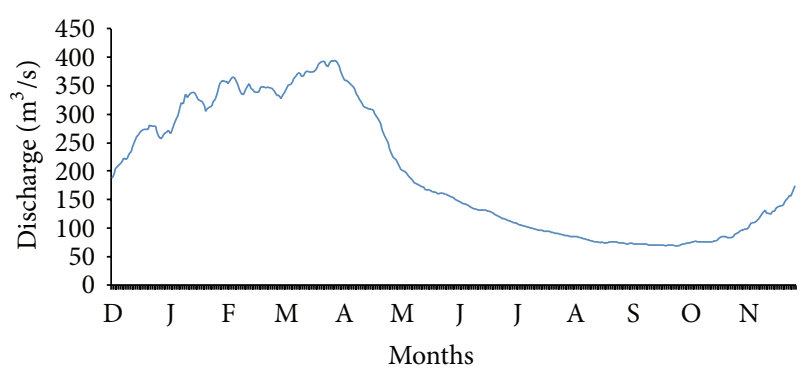

(a)

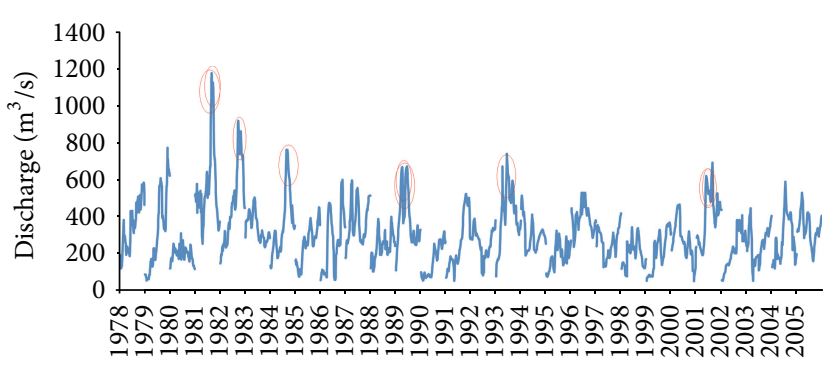

(b)

Figure 4: (a) Streamflow Climatology at Fazenda Santa Maria gauge station from 1978 to 2006, (b) Extremely high-streamflow events as per Table 1 during DJF seasons.

TABle 1: Extreme high river discharge events together with the climate conditions during those events. mLa Niña correspond to La Niña Modoki, respectively.

\begin{tabular}{lc}
\hline $\begin{array}{l}\text { Extremely high discharge } \\
\text { events }\end{array}$ & $\begin{array}{c}\text { Average daily streamflows } \\
\left(\mathrm{m}^{3} / \mathrm{s}\right) / \text { number of days }\end{array}$ \\
\hline \multicolumn{2}{c}{ December-February } \\
\hline $1981-82$ (La Niña) & $587 / 7$ \\
$1981-82$ (La Niña) & $457 / 31$ \\
$1981-82$ (La Niña) & $871 / 23$ \\
$1984-85$ (mLa Niña) & $704 / 10$ \\
$1989-90$ (La Niña) & $604 / 14$ \\
$1989-90$ (La Niña) & $570 / 11$ \\
2001-02 (La Niña) & $579 / 10$ \\
2001-02 (La Niña) & $573 / 8$ \\
$1993-94^{*}$ & $586 / 14$ \\
\hline
\end{tabular}

" refers to "normal year" without any influence of La Niña.

is determined by the product of these two coefficients, that is, by the product of (1) and (2). This is an attempt to search for simulations that try to fit the observed discharge data at high and low discharges simultaneously.

The methodology consists basically of (1) model calibration against a period of six years, (2) model validation over thirty-one years, and (3) model residual trend analysis.

4.1. Model Performance. In the calibration period, the model obtained a performance coefficient Em of 0.54 (6 years) and, in the validation period, Em was equal to 0.32. From Figure 6 it is possible to see that most observed discharges lay inside the uncertainty bounds of $90 \%$ and inside the $\mathrm{max} / \mathrm{min}$ interval. Therefore, the model was validated for the entire time series. The model residuals analysis (Figure 5) does not provide a clear upward trend in the discharges. This means that there may be very little difference between observed and calculated discharge increased along the time. However, a statistical test was carried out to find the significance of the trend on model residual. Kruskal-Wallis test [26] was applied to identify significant difference among the first six years and the last six years (Figure 6). The test showed little difference between the groups (group 1 and group 2, Figure 7)

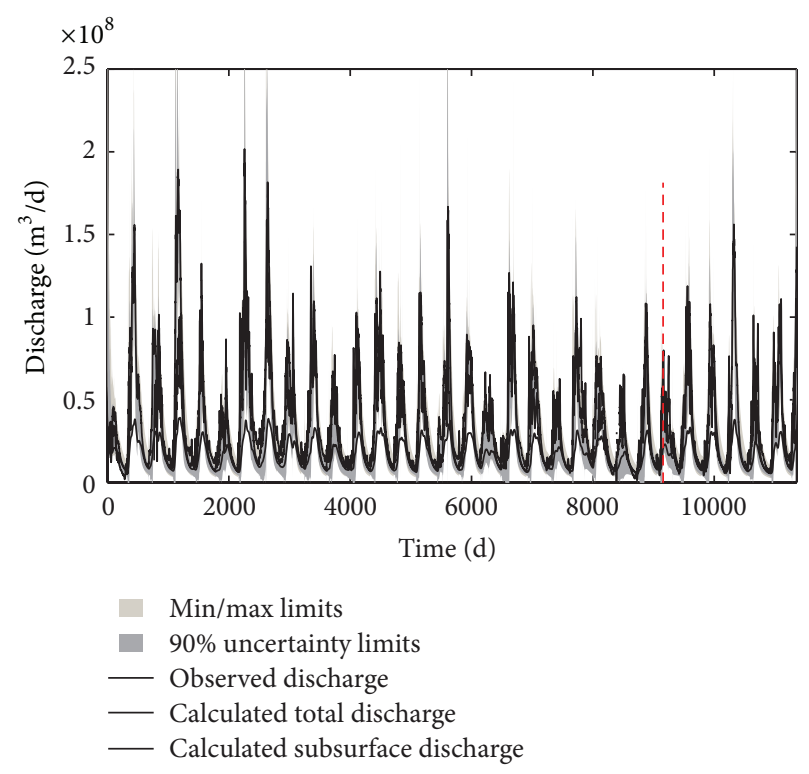

FIGURE 5: Model calibration $(\mathrm{Em}=0.54)$ and validation $(\mathrm{Em}=$ 0.31 ). Period at right from the red dashed line was used for model calibration (2001-2006). The entire period (1978-2006) was used for model validation.

at $P<0.05$. It is probably due to the flux in the form of heat or mass transfers. Nevertheless, the land-use does not have very significant influences on the streamflow characteristics.

\section{Impact of La Niña on Austral Summer}

To examine the possible other component impacts on streamflow of the Paranaíba River, we investigate the climate variability influences on the streamflow at Fazenda Santa Maria gauge station. In this study we found that the La Niña has significant influence on Paranaíba streamflow during austral summer (DJF). As shown in Table 1, 7 out of the total 9 extremely low-discharge events are associated with La Niña during the austral summer season.

Moreover, $80 \%$ of extremely high discharge events are found in the La Niña phase of austral summer (Table 1). Out of the 9 extremely high discharge events during the austral 


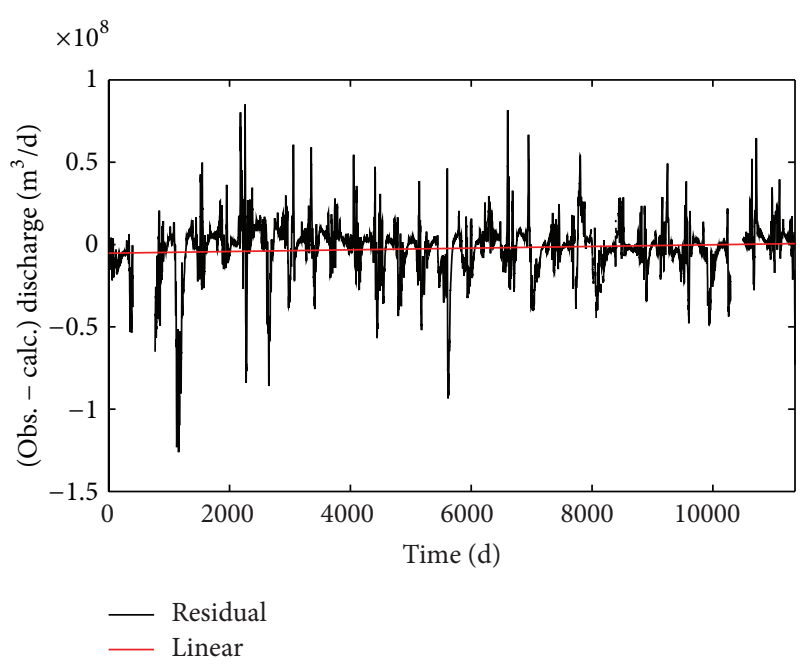

FIGURE 6: Model residual and difference between observed discharge and calculated discharge. Data period from 1978 to 2006.

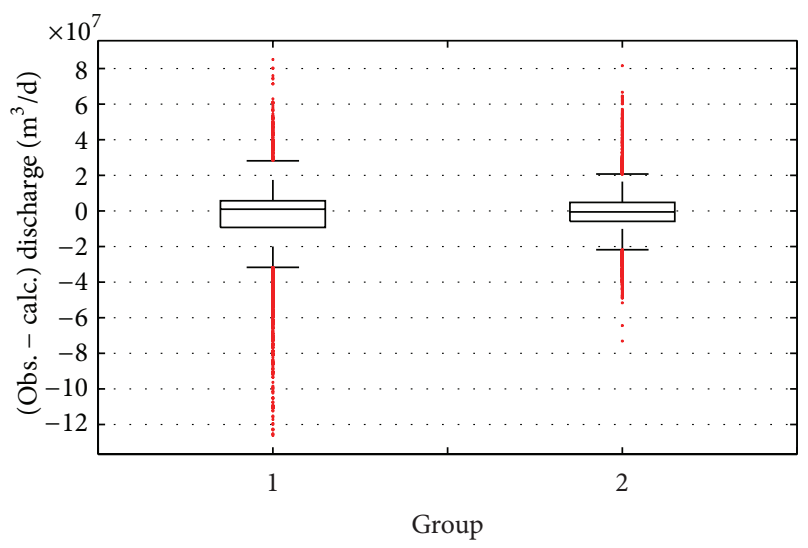

Figure 7: Frequency distribution of the first six years of model residual (group 1) and the last six years (group 2).

summer season, 7 events are associated with La Niña and only one event is associated with La Niña Modoki. The composite anomalies of SST, wind and OLR for all the events during the DJF extremely high streamflow depict a La Niña condition when the eastern Pacific is colder than normal (Figure 8). Unlike the El Nino Modoki related extremely lowstreamflow events (figure not shown), we find here that the tropospheric subsidence associated with La Niña condition is more confined to Amazon basin.

We also notice anomalously strong winds blowing from tropical Atlantic to most parts of Northeast Brazil including the Paranaíba catchment thereby introducing more surface moistures over that region. This also explains the negative OLR anomalies seen above that region and associated extremely high streamflows. Further velocity potential at $200 \mathrm{hPa}$ shows significant convergence over the Paranaíba catchment (Figure 9). If we take the probability of occurrences because of La Niña, La Niña influences around 80\% of the extremely high discharge events.

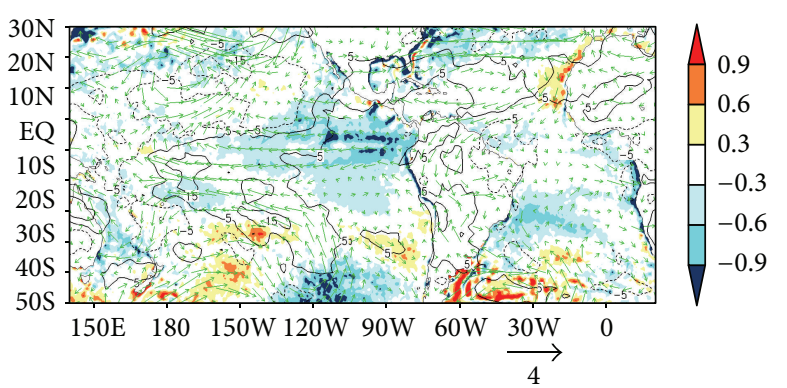

FIgURE 8: Composite anomalies of SST (shaded), wind (stream arrow) and OLR (contour) during DJF or Austral summer season for all extremely high-streamflow events associated with La Niña. Unit for SST is ${ }^{\circ} \mathrm{C}$, for wind is $\mathrm{m} \mathrm{s}^{-1}$, and for OLR is $\mathrm{w} / \mathrm{m}^{2}$. Values above 95\% confidence level from a two-tailed Student's $t$ test are shown.

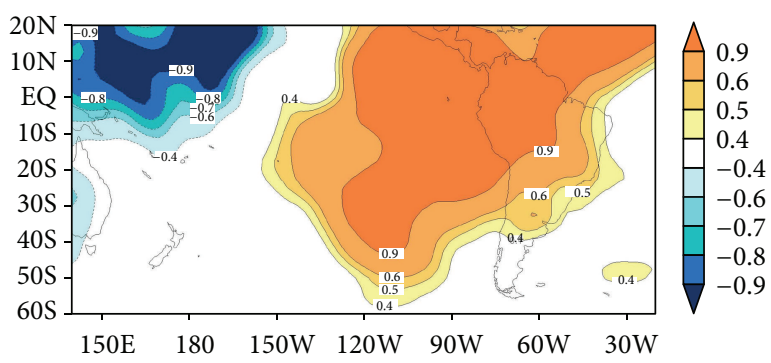

FIgURE 9: Composite anomalies of $200 \mathrm{hPa}$ velocity potential anomalies $\left(\times 10^{6} \mathrm{~m}^{2} \mathrm{~s}^{-1}\right.$; shaded $)$ shaded values are significant at $90 \%$ using $t$-test for DJF or Austral summer season for all extreme highstreamflow events associated with La Niña.

If we compare these analyses with the multivelocity TOPMODEL output, we may conclude that climate variability such as La Niña influences the extremely high discharges events more than any other factor in the Paranaiba catchment, as it is a general acceptance that land-use influenced more to the high discharge events due to soil erosion, sediment deposits, and other anthropogenic land-use changes. Here we recognize that climate modes could cause equal or more amounts of damages to the streamflows.

\section{Conclusions}

In this study we analyzed the daily streamflow of the Paranaíba River at the Fazenda Santa Maria gauge station on investigate the impact of climate variations. Also, we examine the land-use influences to the streamflow by applying the multivelocity TOPMODEL approach by the residual analysis. During DJF or austral summer season we found that $80 \%$ of the extremely high discharge events occurred when eastern Pacific represents a La Niña-like situation.

The La Niña has significantly influenced the extremely high-streamflow characteristic of the Paranaíba River Upper catchment. However, the model residual trend analysis of the TOPMODEL approach cannot quantify the extent of landuse impact, which implies that rainy season's extremely high discharge events of the Paranaíba River catchment at the Fazenda Santa Maria gauge stations are influenced mostly 
by the La Niña phases of the Pacific. Hence, for the societal benefits of this densely populated region climate factors should be investigated properly with special references to the La Niña phase of the Pacific.

\section{Acknowledgments}

NCEP/NCARreanalysis and ANA (Brazilian National Agency of Water Resources) and OISST analysis version 2 AVHRRAMSR (Advanced Very High Resolution Radiometer-Advanced Microwave Scanning Radiometer) products from NCDC (National Climate Data Center) are provided by NOAA (available online), USA.

\section{References}

[1] N. Sahu, S. K. Behera, Y. Yamashiki, K. Takara, and T. Yamagata, "IOD and ENSO impacts on the extreme stream-flows of Citarum river in Indonesia," Climate Dynamics, vol. 39, no. 78, pp. 1673-1680, 2012.

[2] N. Sahu, Y. Yamashiki, S. Behera, K. Takara, and T. Yamagata, "Large impacts of indo-pacific climate modes on the extreme streamflows of citarum river in indonesia," Journal of Global Environment Engineering, vol. 17, pp. 1-8, 2012.

[3] N. Sahu, S. K. Behera, J. V. Ratnam et al., "El Nino Modoki connection to extremely-low streamflow of the Paranaiba River in Brazil," Climate Dynamics, 2013.

[4] S. Hastenrath, "Diagnostic and prediction of anomalous river discharges in northern South America," Journal of Climate, vol. 3, pp. 1080-1096, 1990.

[5] C. R. Mechoso and G. P. Iribarren, "Streamflow in Southeastern America and the Southern oscillation," Journal of Climate, vol. 5, no. 12, pp. 1535-1539, 1992.

[6] J. L. Genta, G. Perez-Iribarren, and C. R. Mechoso, "A recent increasing trend in the streamflow of rivers in southeastern South America," Journal of Climate, vol. 11, no. 11, pp. 2858-2862, 1998.

[7] F. H. S. Chiew and T. A. McMahon, "Detection of trend or change in annual flow of Australian rivers," International Journal of Climatology, vol. 13, no. 6, pp. 643-653, 1993.

[8] A. W. Robertson and C. R. Mechoso, "Interannual and decadal cycles in river flows of southeastern South America," Journal of Climate, vol. 11, no. 10, pp. 2570-2581, 1998.

[9] J. E. Richey, C. Nobre, and C. Deser, "Amazon River discharge and climate variability: 1903 to 1985," Science, vol. 246, no. 4926, pp. 101-103, 1989.

[10] IGAM (Institute of Water Management of Minas Gerais), "Surface water quality monitoring in the Paranaiba river basin during 2007," Annual Report, IGAM, 2008, Portuguese.

[11] P. Aceituno, "On the fluctioning of the Southern oscillation in the South America sector," Monthly Weather Review, vol. 116, no. 3, pp. 505-524, 1988.

[12] J. A. Marengo, "Variations and change in South American streamflow," Climatic Change, vol. 31, no. 1, pp. 99-117, 1995.

[13] N. O. García and W. M. Vargas, "The temporal climatic variability in the 'Rio de la Plata' basin displayed by the river discharges," Climatic Change, vol. 38, no. 3, pp. 359-379, 1998.

[14] R. V. Andreoli and M. T. Kayano, "ENSO-related rainfall anomalies in South America and associated circulation features during warm and cold Pacific decadal oscillation regimes,"
International Journal of Climatology, vol. 25, no. 15, pp. 20172030, 2005.

[15] M. T. Kayano and R. V. Andreoli, "Relations of South American summer rainfall interannual variations with the Pacific Decadal Oscillation," International Journal of Climatology, vol. 27, no. 4, pp. 531-540, 2007.

[16] K. J. Beven, R. Lamb, P. Quinn, R. Romanowicz, and J. Freer, "Topmodel," in Computer Models of Watersh, V. P. Singh, Ed., pp. 627-668, Water Resources Publication, 1995.

[17] Y. Hirabayashi, S. Kanae, K. Motoya, K. Masuda, and P. Doll, "A 59-year (1948-2006) global near-surface meteorological data set for land surface models," Development of Daily Forcing and Assessment of Precipitation Intensity, Hydrological Research Letters, vol. 2, pp. 36-40, 2008.

[18] C. H. B. Priestley and R. J. Taylor, "On the assessment of surface heat flux and evaporation using large-scale parameters," Monthly Weather Review, vol. 100, no. 2, pp. 81-92, 1972.

[19] E. Kalnay, M. Kanamitsu, R. Kistler et al., "The NCEP/NCAR 40-year reanalysis project," Bulletin of the American Meteorological Society, vol. 77, no. 3, pp. 437-471, 1996.

[20] B. Liebman and C. A. Smith, "Description of a complete (Interpolated) outgoing longwave radiation dataset," Bulletin of the American Meteorological Society, vol. 77, pp. 1275-1277, 1996.

[21] R. W. Reynolds, T. M. Smith, C. Liu, D. B. Chelton, K. S. Casey, and M. G. Schlax, "Daily high-resolution-blended analyses for sea surface temperature," Journal of Climate, vol. 20, no. 22, pp. 5473-5496, 2007.

[22] L. B. Leopold, M. G. Wolman, and J. P. Miller, Fluvial Processes in Geomorphology, Dover Publications, 1964.

[23] R. V. Silva, Y. Yamashiki, K. Tatsumi, and K. Takara, "Large-scale runoff routing modeling using TOPMODEL," Annual Journal of Hydraulic Engineering, vol. 54, pp. 91-96, 2010.

[24] R. V. Silva, F. Grison, and M. Kobiyama, "Conceptual investigation of time of concentration: Case study of the Pequeno River watershed, Sao Jose dos Pinhais, PR, Brazil," in From Headwaters To the Ocean, Taniguchi, Ed., Taylor \& Francis Group, London, UK, 2009.

[25] J. E. Nash and J. V. Sutcliffe, "River flow forecasting through conceptual models part I-a discussion of principles," Journal of Hydrology, vol. 10, no. 3, pp. 282-290, 1970.

[26] M. Hollander and D. A. Wolfe, Nonparametric Statistical Methods, John Wiley \& Sons, Hoboken, NJ, USA, 1999. 

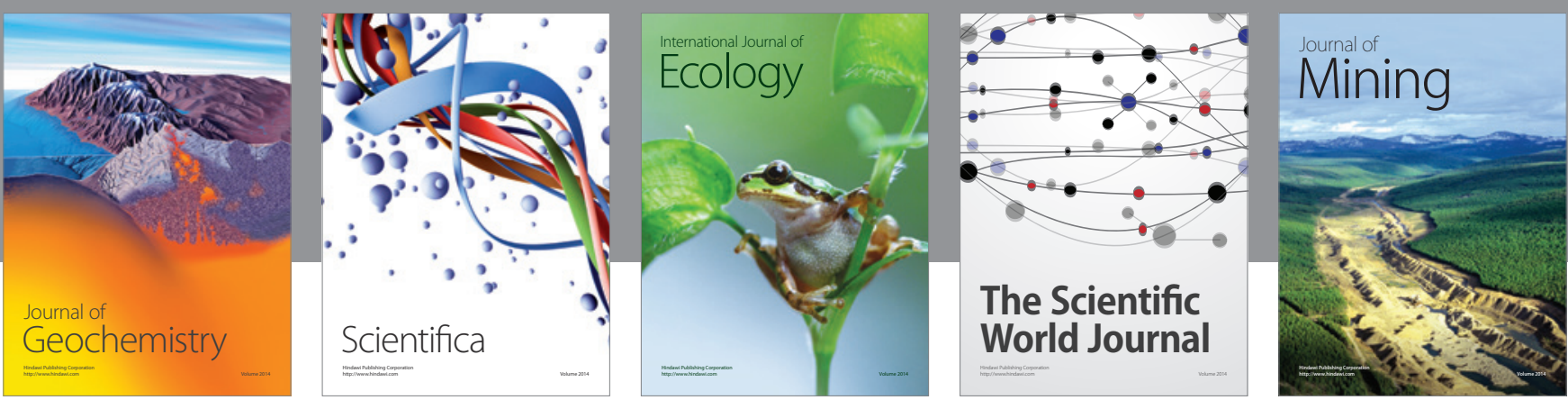

The Scientific World Journal
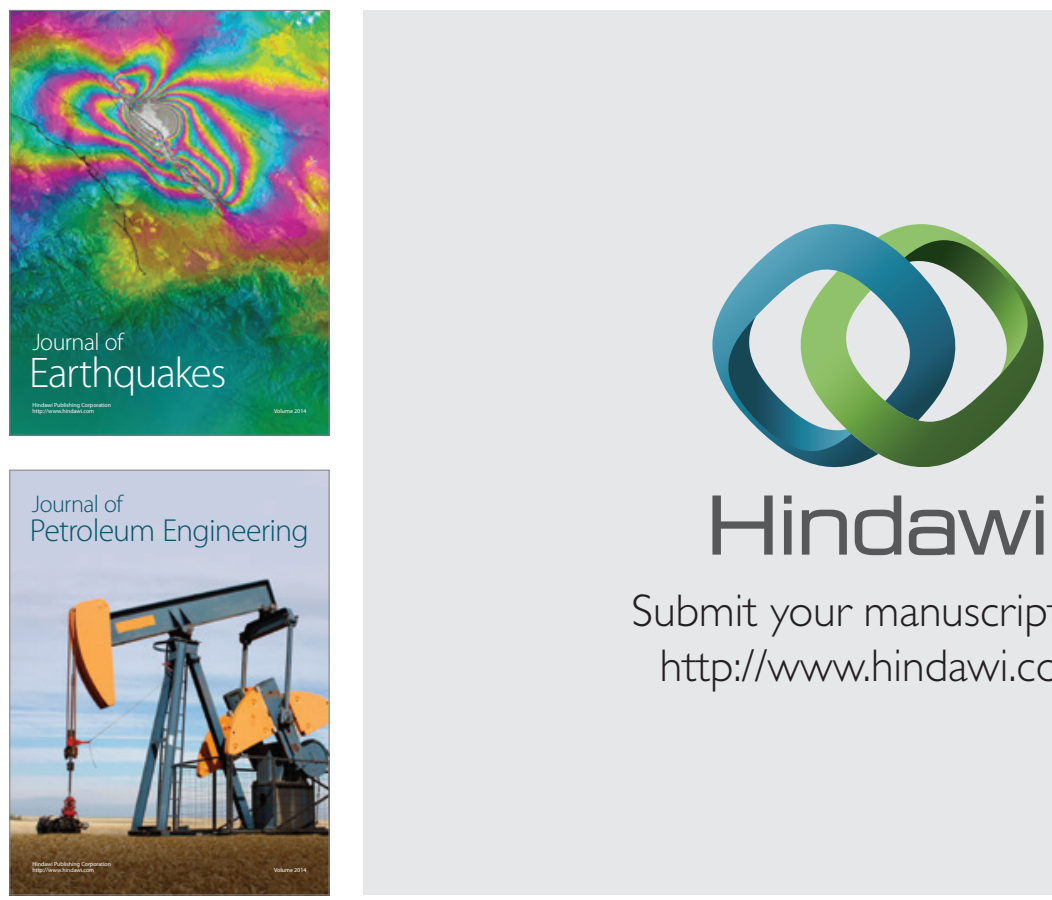

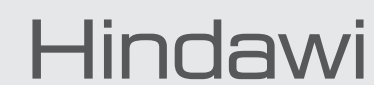

Submit your manuscripts at

http://www.hindawi.com
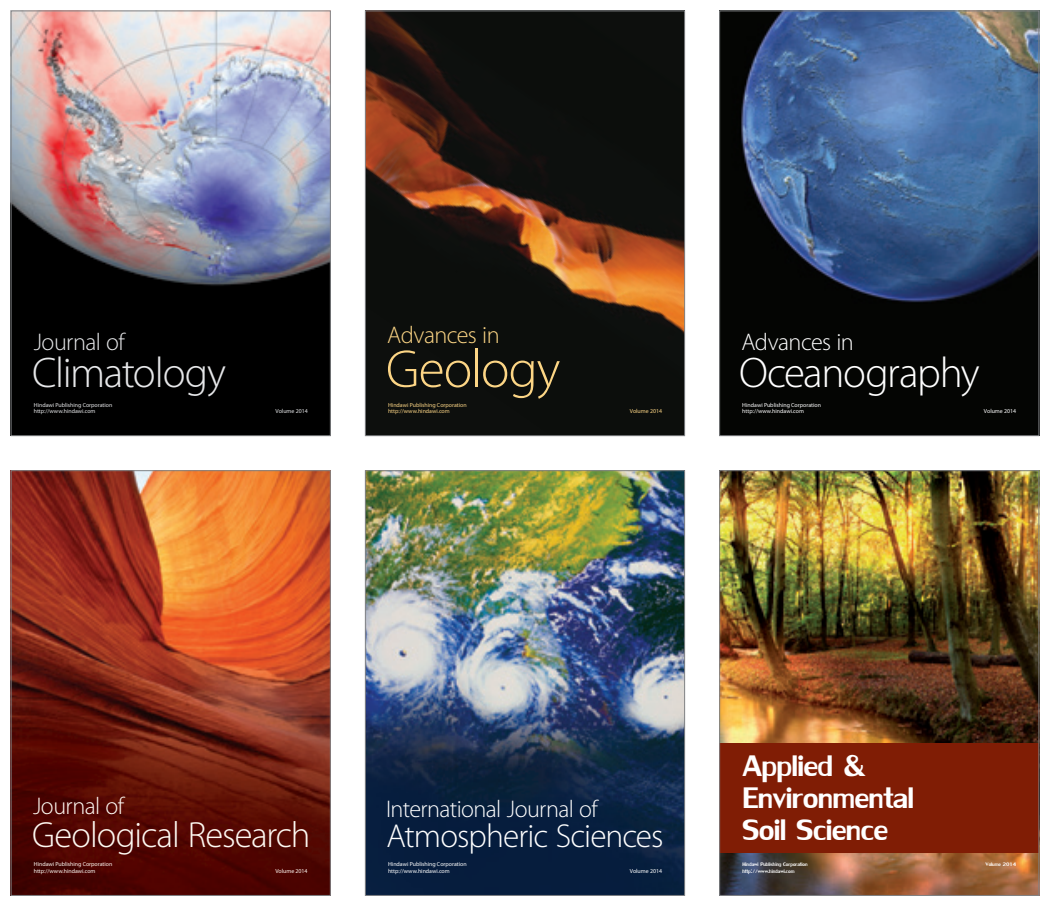
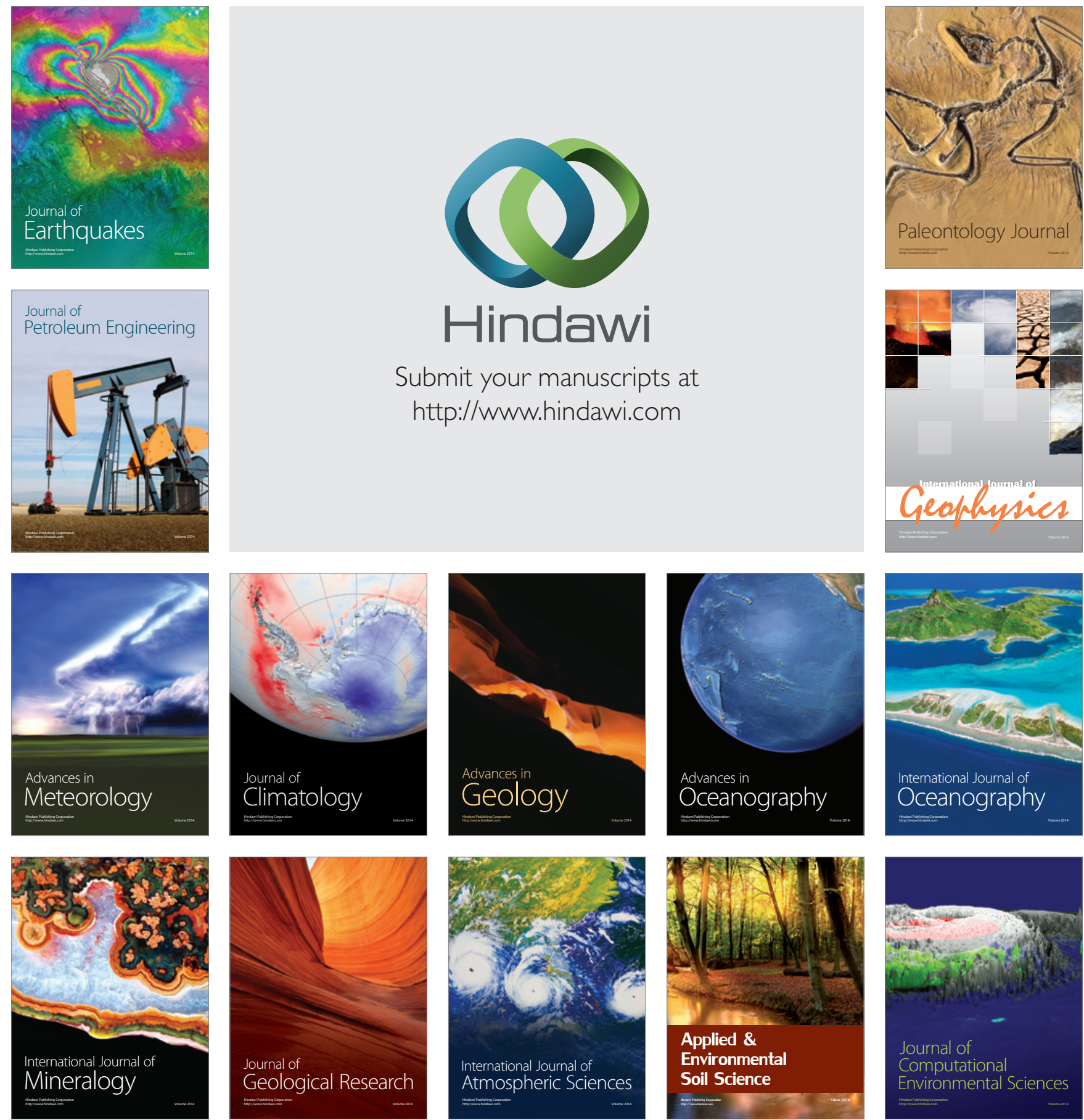